\title{
Developing Moodle-based e-learning on the topic of logarithm for the tenth-grade students of SMA $\mathbf{N} 1$ Sewon
}

\author{
Nor Hasanah*, Uswatun Khasanah \\ Universitas Ahmad Dahlan, Jl. Ahmad Yani, Tamanan, Banguntapan, Bantul DIY \\ 55191 Indonesia \\ *Corresponding e-mail: nor1500006104@webmail.uad.ac.id
}

\begin{abstract}
The development of technology and communication has an impact on all aspects of life, including in the learning process using media. This study aims to develop e-learning platform by using Moodle on logarithmic material for ten grader students of SMA Negeri 1 Sewon. This development research uses the ADDIE model. The subjects of this study were learning material expert, learning media expert, and 10 grader students of SMA Negeri 1 Sewon. Data collection techniques were carried out by interviews, questionnaires, and observations. The data analysis techniques were conducted by converting qualitative data into quantitative data using a Likert scale. The results obtained from experts in the material included in the feasible category, the results obtained by media experts included in the feasible category, and the results of student assessment obtained as a feasible category. Based on these results, it can be concluded that the learning media developed can be used in the process of learning mathematics.
\end{abstract}

Keywords: ADDIE, e-learning, logarithm, Moodle

How to cite: Hasanah, N., \& Khasanah, U. (2020). Template of IJEI: Developing Moodlebased e-learning on the topic of logarithm for the tenth-grade students of SMA N 1 Sewon. International Journal on Education Insight, 1(2), 101-108. DOI: http://dx.doi.org/ijei.v1i2.2618

\section{INTRODUCTION}

The rapid development of the times can be seen with many of the emergences of information and communication technologies that have an impact on almost every aspect, especially on computer applications, where these developments began to require humans to master information and knowledge technology. One of them is based on the internet network that has developed quite rapidly and is widely used by the wider community that is used to support the progress of information such as in the world of education, especially in the process of learning mathematics to be more effective and efficient. According to Pastore (2002), one of the technology-based learning media that can be used to support existing media is a form of e-learning. Therefore, with the rapid development of technology has an impact on the world of education, one of them is the use of e-learning as a learning medium that provides a learning experience that is different from the learning process.

Based on the results of interviews with mathematics teachers in class $\mathrm{X}$ and students of class X MIPA 3 in SMA Negeri 1 Sewon on February 03, 2020, that teaching and learning activities are often carried out using the lecture method. Focused learning activities using books from worksheets and textbooks so that the variation of material that can be used as teaching materials becomes very limited, and material that is considered quite difficult by students in the form of logarithmic material because students are still inclined to be confused 
in working on varied problems, the teacher needs a learning media that is innovative and can be tested anywhere.

In line with this, based on the research results of Samsuddin et al. (2013), teachers are required to create an atmosphere of learning that is effective, innovative, and enjoyable in the learning process. The teacher acts as a motivator and facilitator, changing the paradigm of instructional based learning to constructional based learning, making teachers have to design learning that activates students to hone more skills with independent practice. This is supported by Aditya (2018) which states that "the use of web-based learning media in the form of e-learning can reduce the static atmosphere and can create effective, interesting, interactive learning and can arouse student learning motivation", so that in the mathematics learning process of students is expected to be able to develop competencies in the ability to think logically, analytically, systematically, critically, creatively and collaboratively.

Mathematics is a science with a way of thinking and reason deductively to solve a problem both in science, government, and industry using symbols that are easily understood. Learning according to Muin and Ulfah (2012) is a process of students or individuals in developing ideas or understanding of material or information, whether through mental experience, physical or social experience. According to Fahmi (2018), e-learning is distance learning by utilizing computer technology, computer networks, and the internet. Learning Management System (LMS) is a system where students and teachers can interact with each other in digital classrooms and can access learning materials anytime and anywhere as long as there is a computer network or the internet. Cartono et al. (2015) said that Moodle is a learning platform for a website-based learning environment by maintaining the principles of learning (social instructional pedagogy). Thus, we developed Moodle-based e-learning on the material of logarithmic for ten grader students in SMA Negeri 1 Sewon.

\section{RESEARCH METHOD}

The research used is a research and development method (Research and Development). According to Sukmadinata (2007) research and development or Research and Development are a process or steps to develop a new product or improve existing products, which can be accounted for. This research uses the Analysis, Design, Development, Implementation, and Evaluation (ADDIE) models. The type of data needed is qualitative and quantitative data, with instruments used namely interviews, and questionnaires. The research subjects were Grade X MIPA 3 students of SMA Negeri 1 Sewon.

This research development uses data collection techniques, namely: interviews, questionnaires, and observations. The research data were obtained using the following instruments: a material expert feasibility test questionnaire, a media expert feasibility test questionnaire, and a test questionnaire for student responses.

After the data has been collected, the average score of the questionnaire results will be calculated using the formula:

with

$$
\bar{X}=\frac{\sum x}{N}
$$

$\bar{X}$ is the average score of each component,

$\sum x$ is the sum of the score gained, and

$\mathrm{N}$ is the number of assessed indicators. 
Data that have been analyzed are then converted into qualitative forms such as those contained in Widoyoko (2017) and compared based on the criteria in Table 1.

Table 1. Conversion Score Rating Criteria

\begin{tabular}{ll}
\hline \multicolumn{1}{c}{ Score Interval } & \multicolumn{1}{c}{ Criteria } \\
\hline $\bar{X}>\bar{X}_{l}+1,8\left(S b_{i}\right)$ & Very good \\
$\bar{X}_{l}+0,6\left(S b_{i}\right)<\bar{X} \leq \bar{X}_{l}+1,8\left(S b_{i}\right)$ & Good \\
$\bar{X}_{l}-0,6\left(S b_{i}\right)<\bar{X} \leq \bar{X}_{l}+0,6\left(S b_{i}\right)$ & Fair \\
$\bar{X}_{l}-1,8\left(S b_{i}\right)<\bar{X} \leq \bar{X}_{l}-0,6\left(S b_{i}\right)$ & Poor \\
$\bar{X} \leq \bar{X}_{l}-1,8\left(S b_{i}\right)$ & Inappropriate \\
\hline
\end{tabular}

with

$\bar{X} \quad$ : Average score

$\bar{X}_{l} \quad:$ Average ideal $=\frac{1}{2}$ (maximum score + minimum score $)$

$S b_{i} \quad:$ The standard deviation of the ideal score

$=\frac{1}{6}$ (maximum score - minimum score $)$

maximum score $=\sum \times$ maximum score

minimum score $=\sum \times$ minimum score.

\section{RESULTS AND DISCUSSION}

Analysis of the research data on this development was obtained by collecting qualitative data from the results of the research of the questionnaire instruments which included material expert questionnaires, media questionnaire instruments, and student response instruments. Furthermore, this qualitative data is converted into quantitative data using a Likert scale for the scoring rules. Based on quantitative data the average score is calculated to be classified according to the ideal assessment category so that it can be seen the feasibility/quality of the developed e- learning based learning media.

The feasibility or quality of learning media based on e-learning obtained from the results of data analysis on each questionnaire instrument is described as follows.

The feasibility or quality of the learning material contained in e- learning based learning media has been assessed by material experts consisting of lecturers and teachers. Data from the calculation of the material expert questionnaire can be seen in Table 2.

Table 2. Results of the expert questionnaire calculation results

\begin{tabular}{clll}
\hline No & Validator & Score & Quantitative Data Criteria \\
\hline 1 & Lecturer & 36 & Good \\
2 & Teacher & 37 & Good \\
Average & 36.5 & Good \\
\hline
\end{tabular}

Based on Table 2, it is known that the average score of the assessment by material experts is 36.5. Thus, the feasibility or quality of material from elearning based learning media is included as a feasible criterion.

The feasibility or quality of the developed e-learning based learning media has been assessed by media experts consisting of lecturers and teachers. Data 
from the results of the feasibility calculation from the material expert questionnaire can be seen in Table 3 .

Table 3. Results of the calculation of the media expert questionnaire

\begin{tabular}{cccc}
\hline No & Validator & Score & Quantitative Data Criteria \\
\hline 1 & Lecturer & 59 & Good \\
2 & Teacher & 68 & Good \\
Average & 63.5 & Good \\
\hline
\end{tabular}

Based on Table 3, it is known that the average score of the results of the questionnaire assessment by media experts is 63.5 so that the feasibility of elearning based learning media in terms of media is included in the feasible criteria.

The feasibility or quality of the developed e-learning based learning media has been assessed by high school students of 1 Sewon during the small class test and large class test. The results of student questionnaire data calculations in the small class test can be seen in Table 4 while in the large class test can be seen in Table 4.

Table 4. Results of the questionnaire calculation for small class test students

\begin{tabular}{clll}
\hline No & \multicolumn{1}{c}{ Validator } & Score & Quantitative Data Criteria \\
\hline 1 & Student 1 & 95 & Good \\
2 & Student 2 & 77 & Fair \\
3 & Student 3 & 91 & Good \\
4 & Student 4 & 79 & Fair \\
5 & Student 5 & 78 & Fair \\
6 & Student 6 & 82 & Fair \\
7 & Student 7 & 92 & Good \\
Average & 84.86 & Fair \\
\hline
\end{tabular}

After conducting a small class test, then a large class test is performed. The result is presented in Table 5 .

Table 5. Results of Questionnaire Calculation for Large Class Student

\begin{tabular}{cccc}
\hline No & School & Score & Quantitative Data Criteria \\
\hline 1 & SMA Negeri 1 Sewon & 3310 & \\
Average & 91.94 & Good \\
\hline
\end{tabular}

Based on the two tables above, namely the small class test obtained an average of 84.86 so that it meets the pretty decent criteria, while the large class test is carried out by 36 students and an average of 91.94 is obtained so that it meets the proper criteria in terms of material aspects including the eligibility criteria.

\section{Product feature}

Moodle has several features that teachers can take advantage of, such as Figure 1 , where the teacher can create several sub menus to make it easier for students to choose material and there is a choice of languages that can be used. However, the use of this language option only affects the button menu, not the material.

IJEI, Vol. 1, No. 2, October 2020, 101-108 
There is a discussion feature that the teacher can use to provide space for students to discuss with one another.

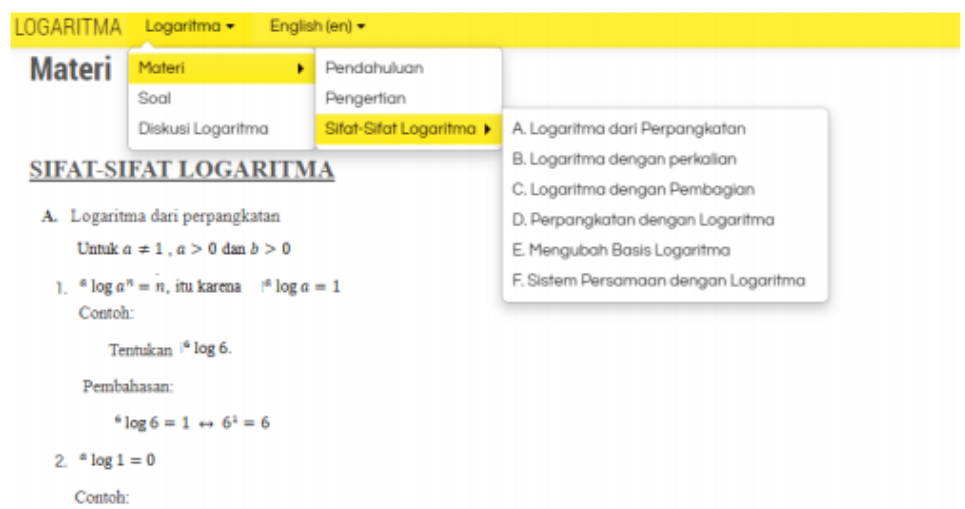

Figure 1. Appearance of sub-material layout

Moodle also has another excellent feature, namely in the tax section the teacher can create assignments or exercises that can be displayed randomly so that it can reduce the cheating that occurs. Interestingly, it can also used in various learning models, such as problem-based learning. Problem-based learning is a learning which utilizes problem as the stimulation of learning (Istiandaru, 2014). Also, in this part of the taxation, the teacher can be creative in making exercises or assignments, where the teacher can make exercises by displaying the discussion if the student answers incorrectly like Figure 2 or does not display a discussion of questions like Figure 3.

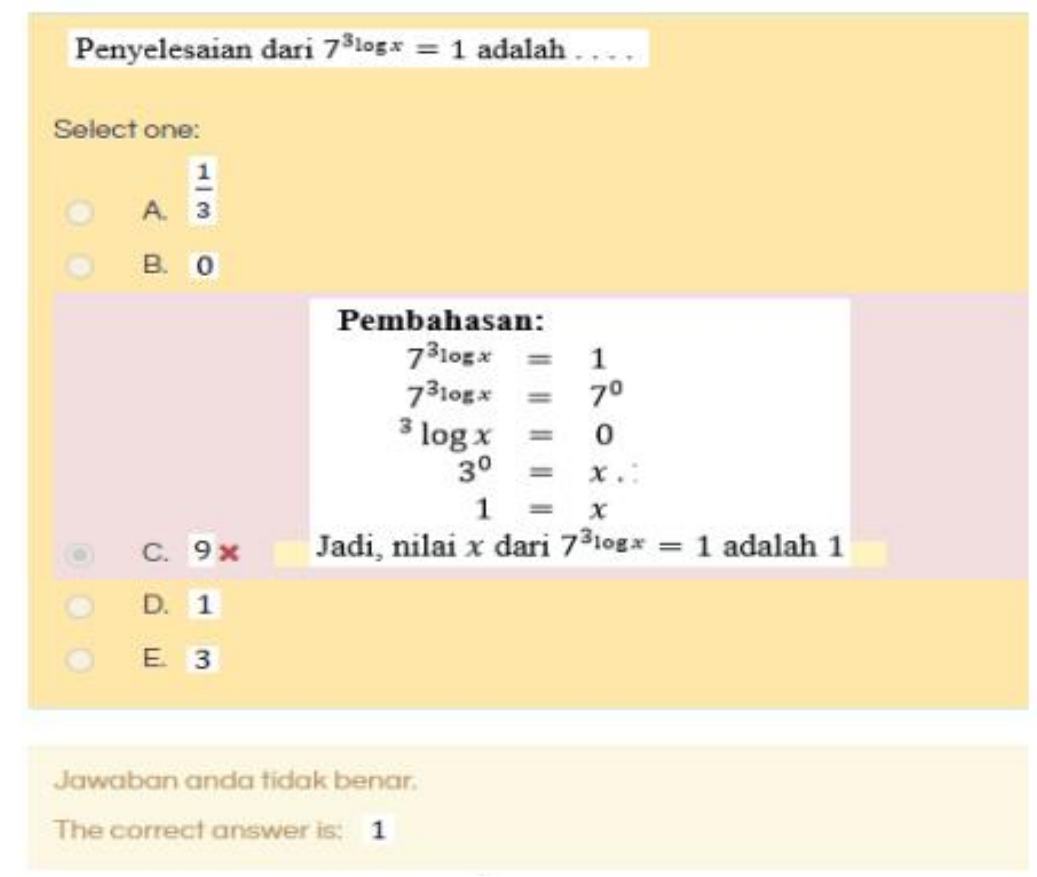

Figure 2. Exercise with explanation 


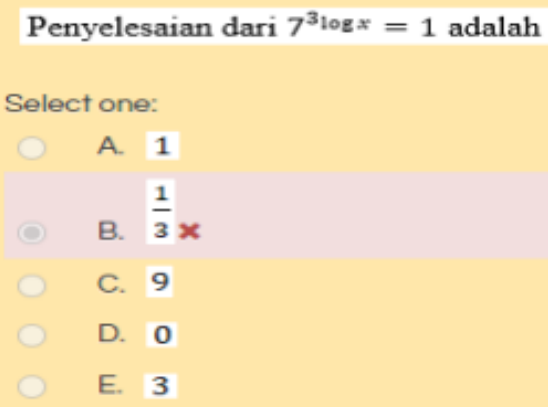

Figure 3. Exercise without explanation

Figure 2 and Figure 3 show the feature of the developed product that teacher could utilize during the learning.

\section{CONCLUSION}

Based on the research results of the development of learning media based on elearning, the conclusions obtained are as follows.

This study begins by conducting an analysis, the results of the analysis obtained that the teacher is still experiencing difficulties in teaching material that is considered quite difficult by students if without using a media, and students find it difficult during the learning process because the learning process often uses less varied learning methods. The next stage is the design of instructional media designs developed in the form of storyboards and workflows in the form of flowcharts. Whereas at the development stage the product was made and also validated by three experts.

Products in the form of learning media based on e-learning and feasibility of mathematics learning media based on e-learning using Moodle are categorized as feasible in terms of material and media get an average final score of 36.5 and 63.50, while when tested in large classes and small classes get an average value of 84.86 and 91.94 . So, it can be stated that the learning media developed is suitable for use by teachers and students in the learning process in any school as long as there is an internet connection available.

\section{REFERENCES}

Aditya, P. T. (2018). Pengembangan media pembelajaran matematika berbasis web pada materi lingkaran bagi siswa kelas VIII. Jurnal Matematika, Statistika dan Komputasi, 15(1), 64-74.

Cartono, C., Fazriyah, N., \& Hendrayana, S. (2019, April). Implementation of Moodle as teaching tool in learning concept science. In 3rd Asian Education Symposium (AES 2018) (pp. 96-98). Atlantis Press.

Fahmi, S. (2018). Membangun Multimedia Interaktif. Yogyakarta: Bildung.

Istiandaru, A. (2014). PBL Pendekatan Realistik Saintifik dan Asesmen PISA untuk Meningkatkan Kemampuan Literasi Matematika. Unnes Journal of Mathematics Education Research, 3(2).

Muin, A., \& Ulfah, R. M. (2012). Meningkatkan hasil belajar matematika siswa dengan pembelajaran menggunakan aplikasi Moodle. Pythagoras: Jurnal Pendidikan Matematika, 7(1).

Pastore, R. (2002). Elearning in education: An overview. In Society for Information Technology \& Teacher Education International Conference (pp. 
275-276). Association for the Advancement of Computing in Education (AACE).

Samsuddin, Y., Rahman, A., \& Nadjib, M. (2016). Pemanfaatan e-learning moodle pada mata pelajaran matematika di SMK Negeri 5 Makassar. KAREBA: Jurnal Imu Komunikasi, 2(1), 65-72.

Sukmadinata, N. S. (2007). Metode Penelitian Pendidikan. Bandung: Remaja Rosdakarya.

Widoyoko, E. P. (2017). Evaluasi Program Pelatihan. Yogyakarta: Pustaka Pelajar. 
This page is intentionally left blank. 